\title{
Effect of the ethanolic extract of pequi (Caryocar brasiliense) peel on acute cardiotoxicity induced by doxorubicin in Wistar rats (Rattus norvegicus albinus)
}

\section{Efeito do extrato etanólico da casca do pequi (Caryocar brasiliense) na cardiotoxicidade aguda induzida por doxorrubicina em ratos Wistar (Rattus norvegicus albinus)}

\author{
Léa Resende Moura ${ }^{1 *}$; Stiwens Roberto Trevisan Orpinelli; \\ Denis Masashi Sugita ${ }^{3}$; Géssica Pinheiro ${ }^{4}$; Mariana Batista Rodrigues Faleiro ${ }^{5}$; \\ Edemilson Cardoso da Conceição ${ }^{6}$; Rosângela de Oliveira Alves Carvalho ${ }^{6}$; \\ Veridiana Maria Brianezi Dignani de Moura ${ }^{6}$
}

\begin{abstract}
This study evaluated the activity of the ethanolic extract of pequi peel (EEPP) and immunostaining with matrix metalloproteinases 2 and 9 (MMP2 and MMP9), and tissue inhibitor of metalloproteinases 1 and 2 (TIMP1 and TIMP2) in the myocardium of rats subjected to acute cardiotoxicity using doxorubicin (DOX). Thirty Wistar rats (six groups of five animals) were used as follows: sham group (SG), water and saline; group G1, $16 \mathrm{mg} / \mathrm{kg}$ of DOX and $300 \mathrm{mg} / \mathrm{kg}$ of EEPP for 17 days; group G2, $16 \mathrm{mg} / \mathrm{kg}$ of DOX and $600 \mathrm{mg} / \mathrm{kg}$ of EEPP for 17 days; group G3, $16 \mathrm{mg} / \mathrm{kg}$ of DOX and $300 \mathrm{mg} / \mathrm{kg}$ of EEPP for 10 days; group G4, $16 \mathrm{mg} / \mathrm{kg}$ of DOX and $600 \mathrm{mg} / \mathrm{kg}$ of EEPP for 10 days; and control group (CG), $16 \mathrm{mg} / \mathrm{kg}$ of DOX. Three days after administering DOX (day 17), euthanasia was performed, and samples were collected for anatomopathological analysis. Myocyte vacuolar degeneration, cardiomyocyte disorganization and myofibrillar fragmentation, necrosis, mononuclear inflammatory infiltrate, Anitschkow cells, fibrosis, congestion, and edema were observed in the hearts of DOX recipients. In G1 and G2, EEPP attenuated myocyte vacuolar degeneration whereas in G4, EEPP attenuated cardiomyocyte disorganization. The percentage of cells immunoreactive for TIMP1 was higher in G1. It was concluded that EEPP minimizes the deleterious effects of DOX on rat myocardium. Doses of 300 and $600 \mathrm{mg} / \mathrm{kg}$ for 17 days attenuate the vacuolar degeneration of myocytes. The dose of $600 \mathrm{mg} / \mathrm{kg}$ for 10 days reduced cardiomyocyte disorganization, and the dose of $300 \mathrm{mg} / \mathrm{kg}$ for 17 days increased TIMP1 expression in the myocardium of DOX-treated rats.
\end{abstract}

Key words: Anthracycline. Cardiotoxicity. Histopathology. Metalloproteinases. TIMP.

\footnotetext{
Prof $^{\mathrm{a}} \mathrm{Dr}^{\mathrm{a}}$, Centro Universitário UniEvangélica, UniEvangélica, Anápolis, GO, Brasil. E-mail: lea_vet@hotmail.com

Prof. Esp., Faculdade Anhanguera de Anápolis, FAA, Anápolis, GO, Brasil. E-mail: stiwensqualittas@hotmail.com

Prof. M.e, Centro Universitário UniEvangélica, UniEvangélica, Anápolis, GO, Brasil. E-mail: dmsugita@gmail.com

4 Médica Veterinária, Universidade Federal de Goiás, UFG, Goiânia, GO, Brasil. E-mail: gskpinheiro@gmail.com

5 Prof ${ }^{a}$ Dr $^{a}$, Faculdade União de Goyazes, FUG, Trindade, GO, Brasil. E-mail: marianafavet@hotmail.com

6 Profs. Drs., Universidade Federal de Goiás, UFG, Goiânia, GO, Brasil. E-mail: farmacotecnicaufg@yahoo.com.br; rosangela2210@gmail.com; vdmoura@hotmail.com

* Author for correspondence
} 


\section{Resumo}

Avaliou-se a ação do extrato etanólico da casca do pequi (EECP) e a imunomarcação de metaloproteinases de matriz 2 e 9 (MMP2 e MMP9), e inibidores teciduais das metaloproteinases de matriz 1 e 2 (TIMP1 e TIMP2), no miocárdio de ratos submetidos à cardiotoxicidade aguda pela doxorrubicina (DOX). Utilizaram-se 30 ratos Wistar, em seis grupos de cinco animais, sendo Grupo Sham (GS) água e salina; (G1) $16 \mathrm{mg} / \mathrm{kg}$ de DOX e $300 \mathrm{mg} / \mathrm{kg}$ de EECP por $17 \mathrm{dias}$; (G2) $16 \mathrm{mg} / \mathrm{kg}$ de DOX e $600 \mathrm{mg} / \mathrm{kg} \mathrm{de}$ EECP por 17 dias; (G3) $16 \mathrm{mg} / \mathrm{kg}$ de DOX e $300 \mathrm{mg} / \mathrm{kg}$ de EECP por 10 dias; (G4) $16 \mathrm{mg} / \mathrm{kg}$ de DOX e $600 \mathrm{mg} / \mathrm{kg}$ de EECP por 10 dias; e grupo controle (GC) $16 \mathrm{mg} / \mathrm{kg}$ de DOX. Três dias após a aplicação da DOX, no dia 17, realizaram-se a eutanásia e colheita de amostras para análises antomopatológicas. No coração dos ratos que receberam DOX observaram-se degeneração vacuolar miocítica, desorganização dos cardiomiócitos e fragmentação das miofibrilas, necrose, infiltrado inflamatório mononuclear, células de Anitschkow, fibrose, congestão e edema. Nos grupos G1 e G2 o EECP atenuou a degeneração vacuolar miocítica e no G4 atenuou a desorganização dos cardiomiócitos. TIMP1 foi constatada em maior porcentagem de células marcadas no grupo de ratos que recebeu $300 \mathrm{mg} / \mathrm{kg}$ do EECP por 17 dias. Conclui-se que o EECP minimiza os efeitos deletérios da DOX no miocárdio de ratos. Nas doses de 300 e $600 \mathrm{mg} / \mathrm{kg}$ por 17 dias atenua a degeneração vacuolar miocítica, a $600 \mathrm{mg} / \mathrm{kg}$ por 10 dias reduz a desorganização dos cardiomiócitos e a $300 \mathrm{mg} / \mathrm{kg}$ por 17 dias aumenta a expressão de TIMP1 no miocárdio de ratos tratados com DOX.

Palavras-chave: Antraciclina. Cardiotoxicidade. Histopatologia. Metaloproteinases. TIMP.

\section{Introduction}

Doxorubicin (DOX), an anthracycline (ANT) antibiotic, is an effective anti-tumor drug used in veterinary medicine. However, its clinical value is limited by the occurrence of cardiomyopathy (STEINHERZ et al., 1991). The cardiotoxicity of DOX depends on the serum concentration of the active ingredient, and doses $>250 \mathrm{mg} / \mathrm{m}^{2}$ induce progressive myocardial degeneration (BRUNTON et al., 2010).

ANTs intercalate with DNA, causing the rupture of single and double DNA strands and the exchange of sister chromatids. Therefore, ANTs promote mutagenesis and carcinogenesis. Moreover, the quinone group generates free radicals in healthy and malignant tissues (IKEDA et al., 1999). The quinone group reacts with cytochrome P450 reductase in the presence of reduced nicotinamide adenine dinucleotide phosphate (NADPH), forming semiquinone radical intermediates, which react with oxygen and produce superoxide anion radicals; in turn, these radicals generate hydrogen peroxide and hydroxyl radicals (BRUNTON et al., 2010).

Previous studies have reported that antioxidants can reduce the cardiotoxicity caused by DOX
(WALKER et al., 2011; XIN et al., 2011). In this respect, the fruit of pequi (Caryocar brasiliense), a plant species found in the Cerrado of Brazil, semideciduous seasonal forest, and limestone forest, is rich in phenols and has potential medicinal use. This fruit is widely used in the cuisine of the midwest region of Brazil. Phenols, flavonoids, tocopherols, phospholipids, amino acids, phytic acid, ascorbic acid, pigments, and sterols are chemical substances with antioxidant activity (GRANADOSPRINCIPAL et al., 2010).

Matrix metalloproteinases (MMPs) are enzymes secreted as inactive proenzymes and are activated by proteolytic cleavage. MMPs degrade the constituents of the extracellular matrix (ECM) and contribute to the formation and remodeling of the ECM. Moreover, MMPs participate in pathological processes (KHASIGOV et al., 2003) and are activated in response to oxidative stress (POTÁČOVÁ et al., 2007). Tissue inhibitors of MMPs (TIMPs) are proteins that regulate the activity of MMPs and help maintain ECM integrity (BREW et al., 2007).

The objective of this study was to evaluate the activity of the ethanolic extract of pequi peel (EEPP) 
by macroscopic and microscopic morphological analysis and the degree of immunostaining with MMP2, MMP9, TIMP1, and TIMP2 in the myocardium of rats subjected to acute cardiotoxicity induced by DOX.

\section{Material and Methods}

This study was approved by the Animal Research Ethics Committee of the Federal University of Goiás (Comissão de Ética no Uso de Animais - CEUA UFG), Goiânia, GO, protocol nº 028/12.

Thirty 3-month old male Wistar rats (Rattus norvegicus albinus) weighing 224-483 grams were used in the experiments. Animals of the same lineage and sex were used to avoid biases, such as hormonal interference. The animals were kept in the animal facility of the Veterinary School and Animal Science of the Federal University of Goiás, Goiânia, GO, in rooms maintained at $21^{\circ} \mathrm{C}$ with an air conditioner (Consul, CBV12, Manaus, Amazonas, Brazil) monitored with a thermometer, and lighting (12-hour cycles) controlled with a timer. The animals received standard chow (Supra, São Leopoldo, Rio Grande do Sul, Brazil) and water ad libitum.

The pequi fruits were carefully collected from pequi trees from a private reserve area in the municipality of Senador Canedo, Goiás, Brazil. The geographical coordinates of the harvest area were defined by GPS triangulation $\left(13^{\circ} 43^{\prime} 08.04^{\prime \prime} \mathrm{S} 50^{\circ}\right.$ $31^{\prime} 44.98^{\prime \prime} \mathrm{O}$ ).

The EEPP was processed from fruits according to a technique described by Moura et al. (2017). DOX was applied intraperitoneally with catheter number 22 after antisepsis with iodopovidone. The animals $(\mathrm{n}=30)$ were separated into six groups of five animals (sham group [SG], G1, G2, G3, G4, and control group [CG]). The study period was 17 days, and DOX and physiological solution were applied on day 14 after the start of the experiment, according to the criteria adapted from Xin et al.
(2011). In G1, G2, G3, G4, and CG, cardiotoxicity was induced by the intraperitoneal administration of $16 \mathrm{mg} / \mathrm{kg}$ of DOX (Adriblastina ${ }^{\circledR}$, doxorubicin, Pfizer, Italy) in a single dose. In the SG, $1 \mathrm{~mL}$ of physiological solution (placebo) was administered intraperitoneally. G1 and $\mathrm{G} 2$ received $300 \mathrm{mg} / \mathrm{kg}$ and $600 \mathrm{mg} / \mathrm{kg}$ of EEPP, respectively, for 17 days by gavage. During the first 7 days, SG, G3, G4, and $C G$ received the same volume of the extract in water by gavage. G3 received $300 \mathrm{mg} / \mathrm{kg}$ daily, G4 received $600 \mathrm{mg} / \mathrm{kg}$ EEPP by gavage from day 7 until the end of the experiment (day 17), totaling 10 days of treatment. From day seven until the end of the study, the CG and SG were given $1 \mathrm{~mL}$ of water daily by gavage. The rats were weighed on days $1,7,14$, and 17 . Gavage was performed every morning, and the doses of EEPP were based on the study by Miguel et al. (2012).

The morphological evaluation was performed on day 17 . The rats were euthanized by anesthetic overdose with isoflurane in a closed inhalation chamber. The anesthetic was administered with a face mask adapted to the animals in $100 \%$ oxygen using a vaporizer at a gas inlet flow of $1 \mathrm{~L} / \mathrm{min}$. The rats' hearts were evaluated by necroscopic examination. In the thoracic cavity, an incision was made in the pericardial sac, and the morphology and amount of adhesions, thickenings, and contents were evaluated. The heart was separated from the respiratory system; the contents of the heart chambers were drained, weighed, and analyzed. For this purpose, a median longitudinal incision was made from the base to the apex of the heart, exposing the heart chambers. The observed changes were photographed and recorded in writing in a worksheet.

Samples of all cardiac chambers were collected and fixed for $48 \mathrm{~h}$ in $10 \%$ buffered formalin for histopathological and immunohistochemical analyses. After this period, the samples were kept in $70 \%$ alcohol until processing, which was performed using routine laboratory techniques for tissue embedding in paraffin. After that, 4- $\mu \mathrm{m}$ histological 
sections were made, placed on histological slides, and stained with hematoxylin and eosin (HE) for evaluation and classification of histomorphologic changes. The slides were analyzed under an optical microscope at magnifications of $4 \mathrm{x}, 10 \mathrm{x}, 40 \mathrm{x}$, and 100x. The histomorphological changes were classified using scores adapted from Pontes et al. (2010) as a function of the intensity of the lesion ( 0 , negative; $1+$, mild; $2+$, moderate; and $3+$, high) and lesion distribution $(0$, absent; $1+$, focal; $2+$, multifocal; and $3+$, diffuse).

For immunohistochemical evaluation, $3-\mu \mathrm{m}$ tissue sections were prepared and placed on adhesive microscope slides (Starfrost ${ }^{\circledR}$, Thermo Fisher Scientific, United States). The sections were deparaffinized, hydrated, washed in running water, and subjected to antigen recovery in a water bath at $96{ }^{\circ} \mathrm{C}$. The endogenous peroxidase activity of the tissues was blocked with $8 \%$ hydrogen peroxide, and nonspecific reactions were blocked with $10 \%$ skimmed milk powder solution (Molico ${ }^{\circledR}$, Nestlé, Brazil). The histological sections were incubated with primary antibodies at a dilution of 1:50 for the anti-MMP2 polyclonal antibody (Abcam, ab110186), 1:200 for the anti-MMP9 polyclonal antibody (DAKO A0150), 1:100 for the anti-TIMP1 polyclonal antibody (Spring E3364), and 1:50 for the anti-TIMP2 polyclonal antibody (Spring E4184) in a humid chamber for $2 \mathrm{~h}$ at $37^{\circ} \mathrm{C}$. The antibodies were replaced with the antibody diluent (ADS125 , Spring) in the tissue sections used as negative controls. The slides were incubated in an Envision Dual Link secondary antibody signal amplification system (DAKO, K4061-1). The reaction was visualized using a diaminobenzidine (DAB) solution (Dako K3468-1). The tissue sections were counterstained with Mayer's hematoxylin, washed, dehydrated, and diaphanized. The histological slides were mounted with coverslips and synthetic resin, and the percentage of immunoreactive cells and intensity of immunostaining were determined. This step was accomplished using a photomicroscope coupled to a digital camera and an image analysis system (DM4000, DFC290 and Leica Application Suite, Leica Microsystems, Germany).

The intensity of immunohistochemical labeling and percentage of cells immunoreactive for MMP2, MMP9, TIMP1, and TIMP2 in the cardiac tissue of rats treated and not treated with DOX with and without EEPP were classified using the criteria adapted from Faleiro et al. (2013), as follows: 0 , none; $1+$, mild; $2+$, moderate; and $3+$, intense (Figure 1); and $0,0 \% ; 1,1-25 \% ; 2,26-50 \% ; 3$, $51-75 \%$, and $4,76-100 \%$, respectively.

Figure 1. Photomicrographs of immunohistochemical labeling scores with anti-MMP2, anti-MMP9, anti-TIMP1, and anti-TIMP2 antibodies in the myocardium of DOX-treated rats treated or nor treated with EEPP. A) negative control $(0+)$; B) mild intensity (1+), anti-MMP9; C) moderate intensity (2+), anti-TIMP2; D) high intensity (3+), anti-MMP2. DAB counterstained with Mayer's hematoxylin. 200x.
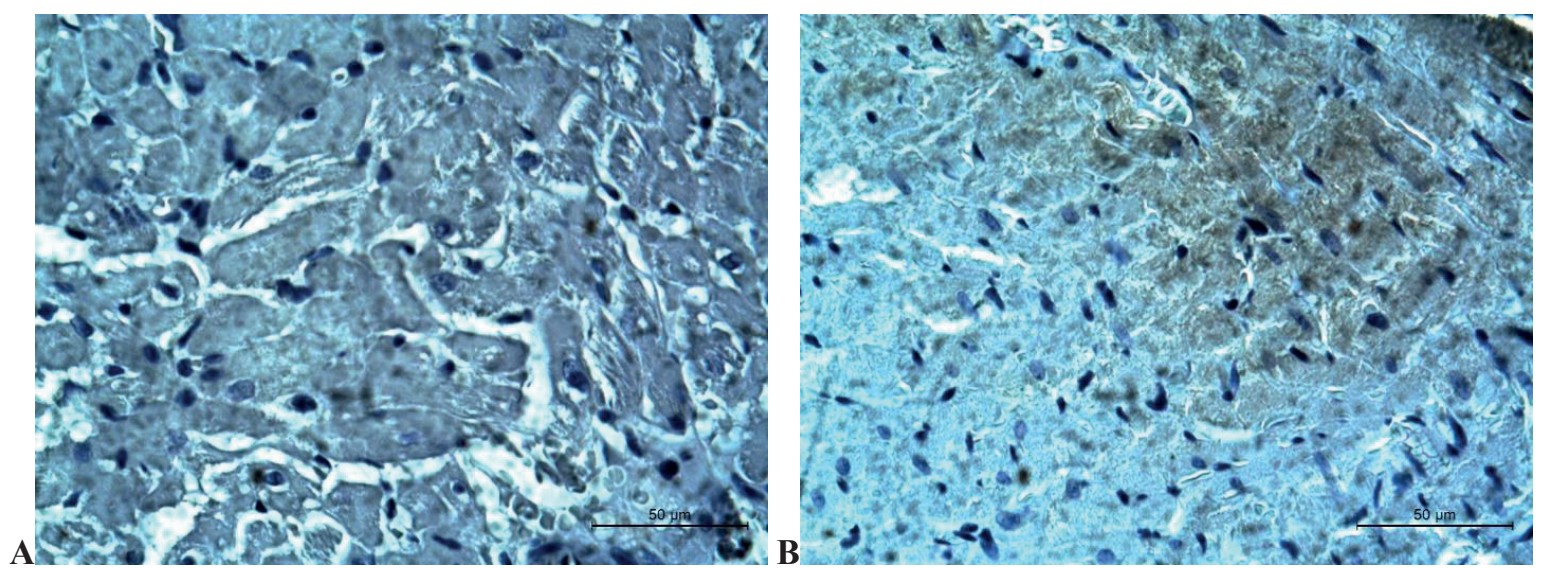

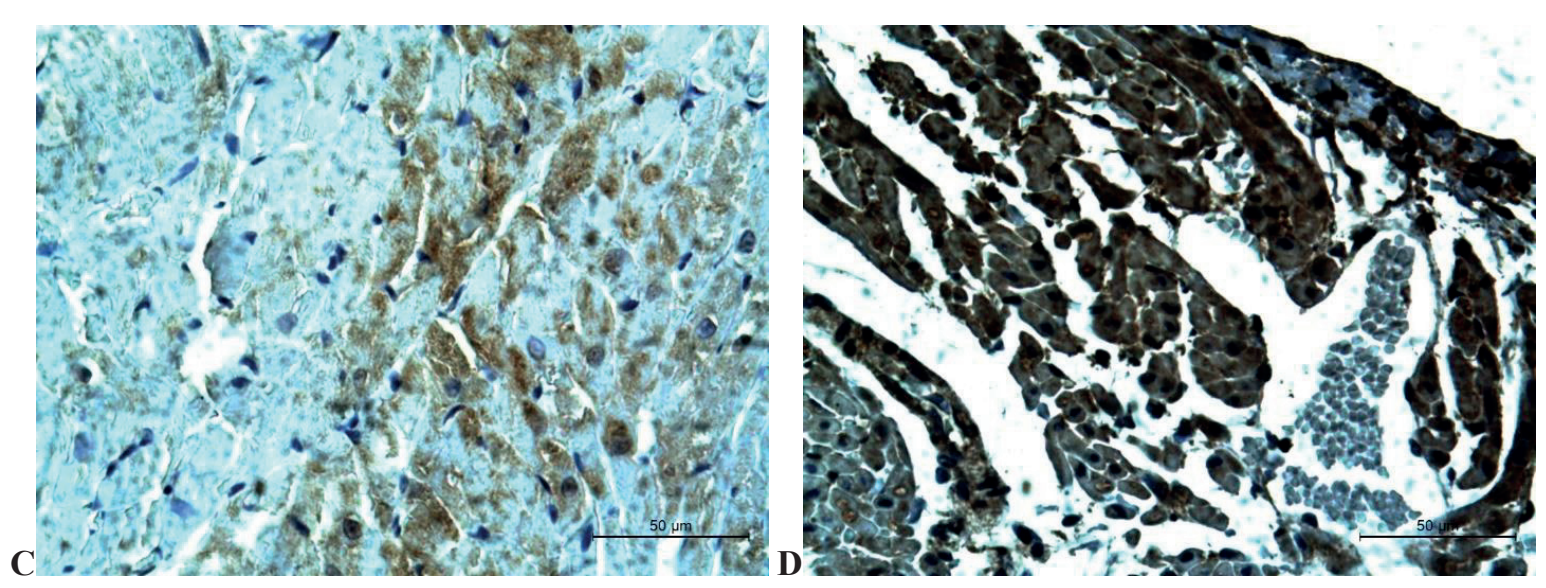

\section{Results}

Two rats $(2 / 5,40 \%)$ of the CG died. However, no macroscopic changes were observed on necropsy in any of the rats of the analyzed groups. Histopathological examination indicated necrosis of cardiomyocytes, which allowed correlating the cause of death with the cardiotoxicity of DOX.

The correlation of animal weight with the period since DOX administration, study groups, and interaction effect was evaluated by non-parametric analysis (ANOVA). There was statistical difference

in at least one of the analyzed time points $(\mathrm{p}<0.001)$, after adjusting the p-values using Bonferroni correction in the multiple comparisons. There was a significant intergroup difference between the first and last time point $(\mathrm{p}<0.001)$, week two and the final week of evaluation $(p<0.001)$, and week three and the final week of evaluation $(\mathrm{p}<0.001)$. There was significant weight loss on day 14 , the day of DOX administration. In the CG (treated with DOX alone), there was a tendency to weight loss, but this loss was not significant in the study period (Figure 2).

Figure 2. Mean values with $95 \%$ confidence interval of the weight of the rats over time per group.

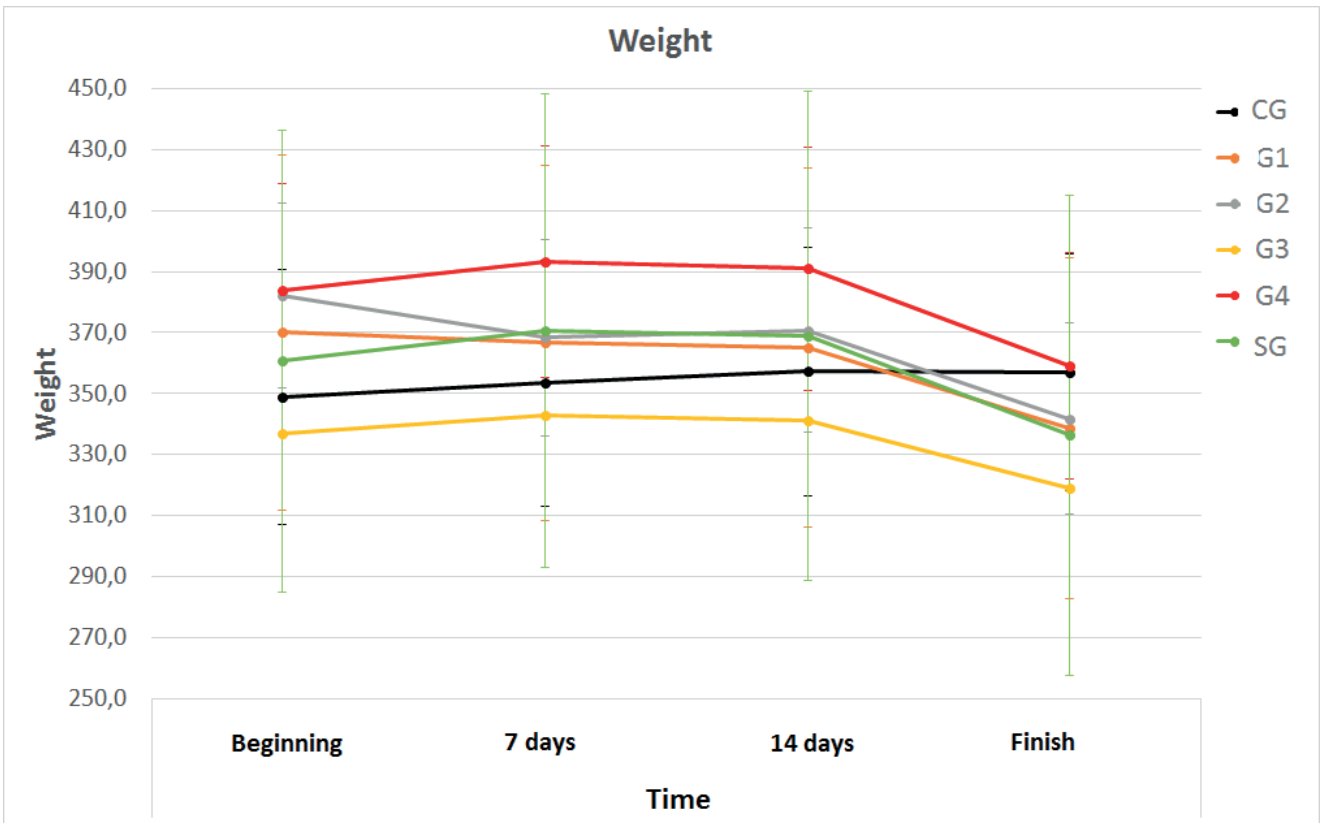

Semina: Ciências Agrárias, Londrina, v. 39, n. 5, p. 1981-1992, set./out. 2018 
The heart weight of the rats of the different groups and the heart weight to body weight ratio were analyzed. The Kruskal-Wallis non-parametric test used for comparing independent groups revealed no significant differences between the groups for any of the studied variables: final body weight $(\chi 2=$ 3.575 , g.1. $=5, \mathrm{p}=0.612)$, heart weight $(\chi 2=5.788$; g.l. $=5 ; \mathrm{p}=0.327)$, and heart weight to body weight ratio $(\chi 2=0.375$, g.1. $=5, p=0.996)$.
Microscopic evaluation of the heart of DOX-treated rats revealed myocytic vacuolar degeneration, vacuolization of the tunica media of arteries and arterioles, cardiomyocyte disorganization and myofibrillar fragmentation, coagulation necrosis, predominance of mononuclear inflammatory infiltrate (with Anitschkow cells in a few cases), fibrosis, congestion, and edema (Figure $3)$.

Figure 3. Photomicrographs of the myocardium of DOX-treated rats. A) G1, predominance of mononuclear infiltrate, with Anitschkow cells (arrows); B) control group (CG), coagulation necrosis, and increased cytoplasmic eosinophilia and nuclear pyknosis; C) G1, myocytic vacuolar degeneration; D) CG, myocytic vacuolar degeneration; E) G3, edema and cardiomyocyte disorganization; F) G2, vacuolization of the arterial tunica media (arrow) (Hematoxylin and Eosin Stain; A, B, D 200x; C, E, F 100x).

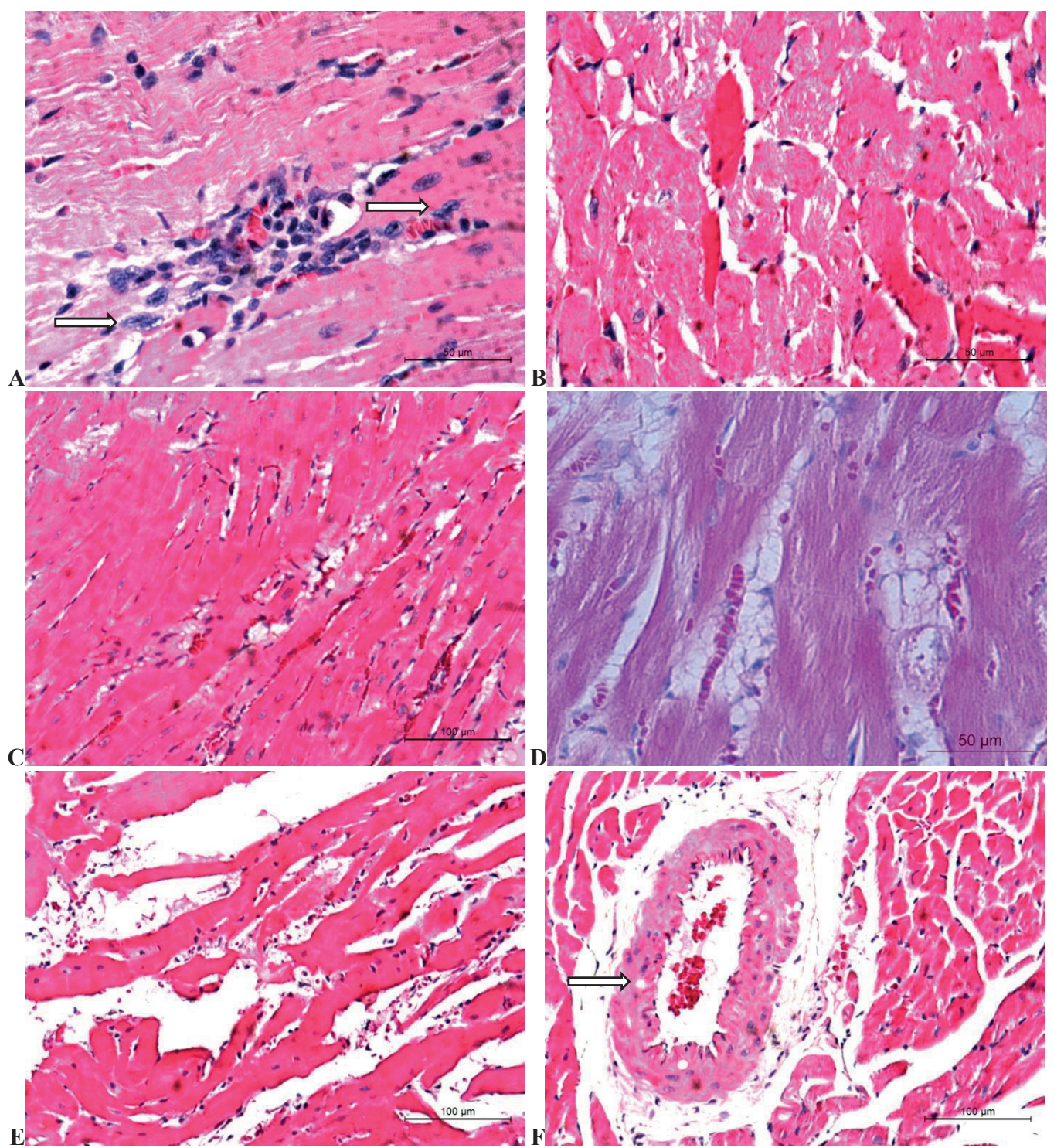


There were differences in immunostaining intensity of vacuolar degeneration $(p=0.0027)$ and distribution of vacuolar degeneration $(\mathrm{p}=0.0159)$ between the SG and G3, G4, and CG (Table 1). However, there were no significant differences between SG, G1, and G2 (Table 1). All groups except for G4 presented significantly $(\mathrm{p}=0.0025)$ higher levels of cardiomyocyte disorganization compared with the SG. The animals from G4 presented mild cardiomyocyte disorganization. The distribution of cardiomyocyte disorganization $(p=0.0011)$, degree of congestion $(p=0.001)$, and distribution of Anitschkow cells $(p=0.0000)$ were significantly different from those of the SG. However, the differences were not significant in the pairwise comparison between the groups (Table 1).

Table 1. Median values of the scores of histopathological changes for each group, classified by intensity (I) and distribution (D).

\begin{tabular}{cccccccccccccccc}
\hline & \multicolumn{3}{c}{ VD } & \multicolumn{2}{c}{ CD } & \multicolumn{3}{c}{ F } & \multicolumn{1}{c}{ CN } & \multicolumn{2}{c}{ AC } & \multicolumn{3}{c}{ MII } & \multicolumn{3}{c}{ CF } \\
\hline Group & $\mathbf{I}$ & $\mathbf{D}$ & $\mathbf{I}$ & $\mathbf{D}$ & $\mathbf{I}$ & $\mathbf{D}$ & $\mathbf{D}$ & $\mathbf{I}$ & $\mathbf{D}$ & $\mathbf{I}$ & $\mathbf{D}$ & $\mathbf{I}$ & $\mathbf{D}$ & $\mathbf{I}$ & $\mathbf{D}$ \\
\hline SG & $0^{\mathrm{b}}$ & $0^{\mathrm{a}}$ & $0^{\mathrm{a}}$ & $0^{\mathrm{a}}$ & $0^{\mathrm{a}}$ & $0^{\mathrm{a}}$ & $0^{\mathrm{a}}$ & $1^{\mathrm{a}}$ & $1^{\mathrm{a}}$ & $1^{\mathrm{a}}$ & $2^{\mathrm{a}}$ & $1^{\mathrm{a}}$ & $3^{\mathrm{a}}$ & $1^{\mathrm{a}}$ & $2^{\mathrm{a}}$ \\
$\mathrm{G} 1$ & $1^{\mathrm{A}}$ & $1^{\mathrm{b}}$ & $2^{\mathrm{A}}$ & $2^{\mathrm{A}}$ & $0^{\mathrm{a}}$ & $0^{\mathrm{a}}$ & $0^{\mathrm{a}}$ & $1^{\mathrm{a}}$ & $2^{\mathrm{A}}$ & $1^{\mathrm{a}}$ & $2^{\mathrm{a}}$ & $2^{\mathrm{A}}$ & $3^{\mathrm{a}}$ & $2^{\mathrm{a}}$ & $2^{\mathrm{a}}$ \\
$\mathrm{G} 2$ & $1^{\mathrm{A}}$ & $1^{\mathrm{b}}$ & $2^{\mathrm{A}}$ & $2^{\mathrm{A}}$ & $0^{\mathrm{a}}$ & $0^{\mathrm{a}}$ & $0^{\mathrm{a}}$ & $1^{\mathrm{a}}$ & $2^{\mathrm{A}}$ & $1^{\mathrm{a}}$ & $2^{\mathrm{a}}$ & $2^{\mathrm{A}}$ & $3^{\mathrm{a}}$ & $2^{\mathrm{a}}$ & $2^{\mathrm{a}}$ \\
$\mathrm{G} 3$ & $1^{\mathrm{B}}$ & $1^{\mathrm{A}}$ & $2^{\mathrm{A}}$ & $2^{\mathrm{A}}$ & $0^{\mathrm{a}}$ & $0^{\mathrm{a}}$ & $1^{\mathrm{a}}$ & $1^{\mathrm{a}}$ & $2^{\mathrm{A}}$ & $1^{\mathrm{a}}$ & $2^{\mathrm{a}}$ & $2^{\mathrm{A}}$ & $3^{\mathrm{a}}$ & $1^{\mathrm{a}}$ & $2^{\mathrm{a}}$ \\
G4 & $1^{\mathrm{B}}$ & $2^{\mathrm{A}}$ & $1^{\mathrm{b}}$ & $2^{\mathrm{A}}$ & $0^{\mathrm{a}}$ & $0^{\mathrm{a}}$ & $1^{\mathrm{a}}$ & $1^{\mathrm{a}}$ & $2^{\mathrm{A}}$ & $1^{\mathrm{a}}$ & $2^{\mathrm{a}}$ & $2^{\mathrm{A}}$ & $3^{\mathrm{a}}$ & $2^{\mathrm{a}}$ & $2^{\mathrm{a}}$ \\
CG & $2^{\mathrm{aB}}$ & $2^{\mathrm{A}}$ & $1^{\mathrm{A}}$ & $2^{\mathrm{A}}$ & $0^{\mathrm{a}}$ & $0^{\mathrm{a}}$ & $2^{\mathrm{a}}$ & $1^{\mathrm{a}}$ & $2^{\mathrm{A}}$ & $1^{\mathrm{a}}$ & $2^{\mathrm{a}}$ & $2^{\mathrm{A}}$ & $3^{\mathrm{a}}$ & $2^{\mathrm{a}}$ & $2^{\mathrm{a}}$ \\
\hline
\end{tabular}

VD: vacuolar degeneration of myocytes, CD: cardiomyocyte disorganization, F: fibrosis, CN: coagulation necrosis (assessed only for distribution), AC: Anitschkow cells, MII: mononuclear inflammatory infiltrate, C: congestion, MF: myofibrillar fragmentation. Different letters in the same column indicate the absence of significant differences. Equal letters in upper and lower case indicate significant differences. Similar letters indicate the absence of significant differences. Kruskal-Wallis test, followed by the Dunn test, at a level of significance of $5 \%$.

The results of the immunohistochemical analysis indicated immunostaining with MMP2, MMP9, TIMP1, and TIMP2 in the cardiomyocytes of all study animals. Moreover, there was a significant difference $(p=0.037)$ in the percentage of cells immunoreactive for TIMP1 between G1 and G2 and between $\mathrm{G} 1$ and $\mathrm{G} 4$, and this percentage was higher in G1 compared with G2 and G4 (Table 2).

Table 2. Scores of the intensity of immunostaining and percentage of cells immunoreactive for TIMP1, TIMP2, MMP2, and MMP9 in the study groups.

\begin{tabular}{ccccccccc}
\hline \multirow{2}{*}{ Group } & \multicolumn{3}{c}{ Intensity of immunostaining } & \multicolumn{3}{c}{ Percentage of cells immunoreactive } \\
\cline { 2 - 8 } & TIMP1 & TIMP2 & MMP2 & MMP9 & TIMP1 & TIMP2 & MMP2 & MMP9 \\
\hline SG & $115,70^{\mathrm{a}}$ & $117,70^{\mathrm{a}}$ & $118,10^{\mathrm{a}}$ & $115,00^{\mathrm{a}}$ & $113,10^{\mathrm{abc}}$ & $118,30^{\mathrm{a}}$ & $222,10^{\mathrm{a}}$ & $115,00^{\mathrm{a}}$ \\
$\mathrm{G} 1$ & $118,70^{\mathrm{a}}$ & $112,60^{\mathrm{a}}$ & $115,60^{\mathrm{a}}$ & $221,00^{\mathrm{a}}$ & $225,30^{\mathrm{b}}$ & $113,20^{\mathrm{a}}$ & $114,90^{\mathrm{a}}$ & $221,00^{\mathrm{a}}$ \\
G2 & $112,10^{\mathrm{a}}$ & $115,30^{\mathrm{a}}$ & $112,50^{\mathrm{a}}$ & $112,00^{\mathrm{a}}$ & $112,00^{\mathrm{c}}$ & $116,10^{\mathrm{a}}$ & $220,00^{\mathrm{a}}$ & $112,00^{\mathrm{a}}$ \\
G3 & $113,50^{\mathrm{a}}$ & $117,40^{\mathrm{a}}$ & $112,50^{\mathrm{a}}$ & $112,00^{\mathrm{a}}$ & $113,10^{\mathrm{abc}}$ & $116,10^{\mathrm{a}}$ & $99,80^{\mathrm{a}}$ & $112,00^{\mathrm{a}}$ \\
G4 & $116,50^{\mathrm{a}}$ & $117,40^{\mathrm{a}}$ & $115,60^{\mathrm{a}}$ & $118,00^{\mathrm{a}}$ & $112,00^{\mathrm{ac}}$ & $116,10^{\mathrm{a}}$ & $117,90^{\mathrm{a}}$ & $118,00^{\mathrm{a}}$ \\
CG & $116,50^{\mathrm{a}}$ & $112,60^{\mathrm{a}}$ & $118,70^{\mathrm{a}}$ & $115,00^{\mathrm{a}}$ & $117,50^{\mathrm{abc}}$ & $113,20^{\mathrm{a}}$ & $88,30^{\mathrm{a}}$ & $115,00^{\mathrm{a}}$ \\
\hline
\end{tabular}

Similar letters in the same column indicate the absence of significant differences in TIMP1 using the multiple comparison test, with Bonferroni correction, and U-Mann Whitney test $(\mathrm{p}<0.05)$. 
There was a negative correlation between TIMP1 and MMP2 for the percentage of immunoreactive cells in $\mathrm{G} 1(\mathrm{p}=0.030)$, i.e., the expression of TIMP1 was decreased as the expression of MMP2 was increased and vice-versa. In contrast, there was a positive correlation between MMP2 and MMP9 ( $p$ $=0.007$ ) for the percentage of immunoreactive cells in the CG, i.e., the level of both markers increased concomitantly (Table 3).

Table 3. Spearman correlation between the analyzed variables as a function of the percentage of immunoreactive cells and intensity of immunostaining in each group.

\begin{tabular}{|c|c|c|c|c|c|c|c|c|c|c|c|c|c|}
\hline & \multirow{3}{*}{$\begin{array}{l}\text { Spearman } \\
\text { Correlation }\end{array}$} & \multicolumn{12}{|c|}{ Groups } \\
\hline & & \multicolumn{2}{|c|}{ SG } & \multicolumn{2}{|c|}{ G1 } & \multicolumn{2}{|c|}{ G2 } & \multicolumn{2}{|c|}{ G3 } & \multicolumn{2}{|c|}{ G4 } & \multicolumn{2}{|c|}{ CG } \\
\hline & & $\mathrm{R}$ & $\mathrm{P}$ & $\mathrm{R}$ & $\mathrm{P}$ & $\mathrm{R}$ & $\mathrm{P}$ & $\mathrm{R}$ & $\mathrm{P}$ & $\mathrm{R}$ & $\mathrm{P}$ & $\mathrm{R}$ & $\mathrm{P}$ \\
\hline \multirow{6}{*}{ 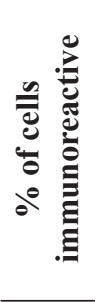 } & TIMP1/TIMP2 & 0,50 & 0,391 & $-0,17$ & 0,789 & . & . & $-0,79$ & 0,111 & . & . & 0,65 & 0,239 \\
\hline & TIMP1/MMP2 & $-0,47$ & 0,423 & $-0,91$ & $0,030^{\mathrm{CR}}$ & . & . & 0,00 & 1,000 & . & . & $-0,40$ & 0,510 \\
\hline & TIMP1/MMP9 & 0,65 & 0,239 & 0,41 & 0,495 & . & . & 0,00 & 1,000 & . & . & 0,00 & 1,000 \\
\hline & TIMP2/MMP2 & 0,00 & 1,000 & 0,00 & 1,000 & $-0,41$ & 0,495 & 0,25 & 0,685 & $-0,36$ & 0,548 & $-0,61$ & 0,272 \\
\hline & TIMP2/MMP9 & 0,65 & 0,239 & $-0,41$ & 0,495 & 0,25 & 0,685 & 0,25 & 0,685 & 0,61 & 0,272 & $-0,17$ & 0,789 \\
\hline & MMP2/MMP9 & 0,30 & 0,619 & $-0,56$ & 0,327 & 0,41 & 0,495 & 1,00 & . & 0,30 & 0,628 & 0,61 & 0,272 \\
\hline \multirow{6}{*}{ 导 } & TIMP1/TIMP2 & 1,00 & $\cdot$ & 0,15 & 0,807 & $-0,41$ & 0,495 & 0,34 & 0,571 & 1,00 & . & 0,65 & 0,239 \\
\hline & TIMP1/MMP2 & 0,00 & 1,000 & 0,56 & 0,327 & $\cdot$ & $\cdot$ & $\cdot$ & $\cdot$ & 0,00 & 1,000 & 0,65 & 0,239 \\
\hline & TIMP1/MMP9 & 0,00 & 1,000 & 0,19 & 0,764 & 0,41 & 0,495 & 0,73 & 0,165 & 0,65 & 0,239 & 0,00 & 1,000 \\
\hline & TIMP2/MMP2 & 0,00 & 1,000 & 0,41 & 0,495 & & . & & . & 0,00 & 1,000 & 0,67 & 0,219 \\
\hline & TIMP2/MMP9 & 0,00 & 1,000 & $-0,41$ & 0,495 & 0,25 & 0,685 & 0,79 & 0,111 & 0,65 & 0,239 & $-0,17$ & 0,789 \\
\hline & MMP2/MMP9 & 0,97 & $0,007^{\mathrm{CR}}$ & 0,25 & 0,685 & . & . & . & . & 0,41 & 0,495 & 0,17 & 0,789 \\
\hline
\end{tabular}

CR Strong negative correlation between TIMP1 and MMP2 and strong positive correlation between MMP2 and MMP9.

${ }^{R:}$ Correlation between the evaluated variables.

P: P-value

\section{Discussion}

Two mice from the CG died a few hours before euthanasia. The mortality rate $(6.66 \%)$ was similar to that observed by Xin et al. (2011), wherein one rat $(3.2 \%)$ died at a DOX dose of $10 \mathrm{mg} / \mathrm{kg}$. In their study, euthanasia was performed 3 days after administering DOX, and the low mortality rate may be related to the shorter waiting period for euthanasia. In contrast, mortality rates $>50 \%$, were reported by Ferreira et al. (2007) and Khan et al. (2005) at a dose of $16 \mathrm{mg} / \mathrm{kg}$ of DOX (four doses of $4 \mathrm{mg} / \mathrm{kg}$ per week); furthermore, in this study, mortality occurred only in the group that received DOX without EEPP. Therefore, it is inferred that the antioxidant activity of EEPP, evidenced by the reduction of myocardial lesions on microscopic examination in rats that received EEPP, also reduces the mortality of rats subjected to acute cardiotoxicity by DOX.

The absence of macroscopic alterations in our sample may be related to the short period between the application of DOX and euthanasia because Ferreira et al. (2007) reported serous fluid accumulation in the pericardium and peritoneal cavity of rats treated with the same dose of DOX using the same route of administration; however, the dose was fractionated in four weekly applications, and the interval between DOX application and euthanasia was longer. It should be noted that even without macroscopic evidence of DOX-induced 
cardiotoxicity, the microscopic changes confirm the deleterious effects of the drug, even in cases in which the period from DOX administration to biopsy collection was short, and a similar result was observed by Karimi et al. (2005) and Xin et al. (2011).

The analysis of the mean weight of the rats of each group indicated that G1, G2, G3, and G4 presented weight loss in the last time point analyzed and, in the CG, there was a tendency to weight loss. These findings may be due to the toxic effects of DOX and the palatability of EEPP. The possibility of esophagitis or even gastritis induced by EEPP was initially considered, but this possibility was discarded on necroscopic examination. These results may also be due to the deleterious effects of the drug, especially in animals undergoing chemotherapy, because the dose of DOX to be used depends on the weight of the animals. Therefore, the extract should be prepared and administered in a way to avoid rejection of feed by the animals after gavage. Similar results were described by Ferreira et al. (2007), who observed a significant decrease in weight using lycopene to treat DOX-induced cardiotoxicity.

There was no significant intergroup difference in the heart weight and heart weight to body weight ratio. Previous studies reported that the DOXtreated animals developed dilated cardiomyopathy (PONTES et al., 2010) and changes in the heart weight to final body weight ratio (DUDNAKOVA et al., 2003; KHAN et al., 2005; XIN et al., 2011). However, these changes were not observed in our sample possibly because of the brand of DOX used, the DOX dose used, and the period from DOX application to biopsy collection. Different results were found by Khan et al. (2005), whereby heart weight was decreased. Similarly, Dudnakova et al. (2003) used a single dose of $2.2 \mathrm{mg} / \mathrm{kg}$ DOX in rats and observed that the heart weight to final body weight ratio was decreased. In these studies, the period of evaluation was longer than that used in this study.
Yu et al. (2005) reported that the histopathological changes from DOX-induced cardiotoxicity allow the definitive diagnosis of the condition, and the main findings included myocyte vacuolar degeneration and loss of myofibrils. The study animals presented with myocyte vacuolar degeneration, vacuolization of the tunica media of arteries and arterioles, cardiomyocyte disorganization and myofibrillar fragmentation, coagulation necrosis, mononuclear inflammatory infiltrate (with the presence of Anitschkow cells in a few cases), fibrosis, congestion, and edema. These results are similar to those reported by Ferreira et al. (2007) using $16 \mathrm{mg} /$ $\mathrm{kg}$ DOX in rats in four doses of $4 \mathrm{mg} / \mathrm{kg}$ per week. Khan et al. (2005) used a similar experimental design in mice and observed changes similar to those of this study, including loss of myofibers and focal myocytic vacuolar degeneration.

Similar histopathological findings were described by Iqbal et al. (2008) with one intraperitoneal injection of $20 \mathrm{mg} / \mathrm{kg}$ of DOX in rats. The observed changes were myofibrillar degeneration, inflammatory infiltrate, and edema in a group of animals subjected to euthanasia 2 days after DOX application. The group of animals subjected to euthanasia 7 days after DOX application presented with focal muscle fiber necrosis, edema, hemorrhage, and congestion, suggesting that the microscopic findings depend on the time elapsed from drug application to biopsy collection.

With regard to the microscopic findings related to the degree and distribution of myocytic vacuolar degeneration, the groups SG, G1, and G2 did not differ statistically, indicating that EEPP minimized the cardiotoxic effects of DOX when used for 14 days, as was the case for G1 $(300 \mathrm{mg} / \mathrm{kg})$ and G2 $(600 \mathrm{mg} / \mathrm{kg})$. The degree of cardiomyocyte disorganization was lower in G4 than in the other groups but was similar between G4 and SG, demonstrating that EEPP at the dose of $600 \mathrm{mg} / \mathrm{kg}$ has antioxidant activity. Other studies determined the action of antioxidants and used DOX to induce cardiotoxicity and observed cardiac protection on 
histopathology and other analyses. Ferreira et al. (2007) reported that the use of lycopene reduced the accumulation of interstitial collagen. Xin et al. (2011) observed a reduction in myofibrillar disorganization, creatine kinase levels, and myocardial conduction abnormalities using the fruit of Lycium barbarum, a plant used in traditional Chinese medicine with antipyretic, anti-inflammatory, and anti-aging properties. Khan et al. (2005) reported that the degree of myocardial degeneration was decreased with the use of the Cyanobacteria Spirulina.

Anti-MMP2 and anti-MMP9 antibodies and their inhibitors (TIMPs) have been used to analyze myocardial remodeling in DOX-induced cardiotoxicity, both acute (KIZAKI et al., 2006) and chronic (ADAMCOVÁ et al., 2010). All MMPs and TIMPs were immunoexpressed in the cardiomyocytes of rats of all groups. These findings are consistent with those of Li et al. (2000), wherein MMPs were found in the myocardium and could degrade ECM components of the heart. In contrast, Silva (2014) measured the myocardial expression of MMP2 and MMP9 by zymography in rabbits with DOX-induced cardiomyopathy at a dose of $12 \mathrm{mg} /$ $\mathrm{kg}$ and observed that only the active form of MMP2 was expressed in this tissue; in addition, the levels of MMP2 did not differ significantly between the control and DOX-treated group, and the inactive and active forms of MMP9 were not detected in the tissue samples examined. These differences may be related to the applied dose, differences between the animal species used, time of evaluation after drug application, and the detection techniques used.

Although it was possible that MMP2 levels were increased in the DOX-treated groups, considering that oxidative stress may activate MMPs, Ivanová et al. (2012) studied mice with DOX-induced cardiomyopathy and found that the activity of proMMP2 in the myocardium was increased after 8 weeks of induction at the accumulated dose of $15 \mathrm{mg} / \mathrm{kg}$. In the present study, although the accumulated dose was $16 \mathrm{mg} / \mathrm{kg}$, which is higher than in the study of Ivanová et al. (2012), it is believed that the time elapsed after DOX application affected the expression of these proteins, which has been observed by Ivanová et al. (2012). In this sense, Kizaki et al. (2006) performed a study to determine the expression curves of these proteins, correlating them with the time elapsed after DOX application. The protein levels were determined in rat myocardium at days 1,2 , and 4 after DOX application. The authors observed that the expression of MMP2 and MMP9 was increased on day 2. The expression of MMP2 was increased approximately 2-fold on days 1 and 2. The expression of MMP9 did not differ significantly in the analyzed groups on day 1 but was increased significantly on days 2 and 4.

In the present study, immunostaining with MMP9 was mild and lower than that with MMP2, TIMP1, and TIMP2. In contrast, Adamcová et al. (2010) did not identify the inactive or active form of MMP9 in the myocardial tissue of rabbits. These results suggest that MMP9 does not participate in the early events of acute cardiotoxicity caused by DOX, and this may be due to the absence of a typical inflammatory infiltrate because MMP9 is strongly associated with leukocytes (SILVA, 2014), and the amount of inflammatory infiltrate found in this study was moderate. Similarly, Ivanová et al. (2012) did not find the inactive or active form of MMP9 in the myocardial tissue of rats. However, Aupperle et al. (2007) used immunohistochemistry and found that the expression of MMP1, MMP2, and MMP9 was increased in rabbit cardiomyocytes with DOX-induced cardiomyopathy compared with animals from a sham group.

In this study, the percentage of cells immunoreactive for TIMP1 was higher in G1, which may indicate a protective effect by EEPP because the rats in this group received $300 \mathrm{mg} / \mathrm{kg}$ of EEPP. There is a strong interest in using TIMPs as therapeutic drugs. Considering that the constant remodeling of the ECM is regulated by MMPs, which in turn are 
affected by growth factors and cytokines, previous studies correlated these factors with the gelatinolytic activity of MMPs. In this sense, anti-TNF therapies have been used to reduce cardiac remodeling and cardiac dilatation in humans with heart failure. Li et al. (2000) tested the activity of AdTNFRI, an anti-TNF, and found that the expression of MMP2 and MMP9 was decreased. The comparison of different therapeutic strategies using EEPP in the present study indicated no significant differences in the activity of MMP2, MMP9, and TIMP2. However, TIMP1 expression was increased in the group treated with $300 \mathrm{mg} / \mathrm{kg}$ EEPP. Although it was expected that the increase in TIMP1 expression would decrease MMP expression, this result was not observed. The expression of these MMPs might have increased if TIMP1 immunoexpression had not increased. These results indicate that natural antioxidants such as EEPP may have therapeutic success in treating this disease.

\section{Conclusios}

EEPP attenuates the deleterious effects of DOX on the myocardium of rats subjected to druginduced acute cardiotoxicity. EEPP doses of 300 and $600 \mathrm{mg} / \mathrm{kg}$ for 17 days attenuate myocyte vacuolar degeneration. An EEPP dose of $600 \mathrm{mg} / \mathrm{kg}$ for 10 days reduces cardiomyocyte disorganization. An EECP dose of $300 \mathrm{mg} / \mathrm{kg}$ for 17 days increases TIMP1 expression in the myocardium of DOXtreated rats.

\section{Acknowledgments}

The authors are grateful to the Coordination of Improvement of Higher Education Personnel (Coordenação de Aperfeiçoamento de Pessoal de Nível Superior - CAPES) for the doctoral scholarship and to the National Council for Scientific and Technological Development (Conselho Nacional de Desenvolvimento Científico e Tecnológico - CNPq) for funding this study.

\section{References}

ADAMCOVÁ, M.; POTÁČOVÁ, A.; POPELOVÁ, O.; STĚRBA, M.; MAZUROVÁ, Y.; AUPPERLE, H.; GERŠL, V. Cardiac remodeling and MMPs on the model of chronic daunorubicin-induced cardiomyopathy in rabbits. Physiological Research, Praha, v. 59, n. 5, p. 831-836, 2010.

AUPPERLE, H.; GARBADE, J.; SCHUBERT, A.; BARTEN, M.; DHEINS, S.; SCHOON, H. A.; MOHR, F. W. Effects of autologous stem cells on immunohistochemical patterns and gene expression of metalloproteinases and their tissue inhibitors in doxorubicin cardiomyopathy in a rabbit model. Veterinary Pathology, Washington, v. 44, n. 4, p. 494-503, 2007.

BREW, K.; DINAKARPANDIAN, D.; NAGASE, H. Tissue inhibitors of metalloproteinases: evolution, structure and function. Biochimica et Biophysica Acta - Protein Structure and Molecular Enzymology, Amsterdam, v. 1477, n. 1-2, p. 267-283, 2007.

BRUNTON, L. L.; LAZO, J. S.; PARKER, K. L. Goodman \& Gilman, as bases farmacológicas da terapêutica. 11. ed. Rio de Janeiro: Mc Graw, 2010. 1848 p.

DUDNAKOVA, T. V.; LAKOMKIN, V. L.; TSYPLENKOVA, V. G.; SHEKHONIN, B. V.; SHIRINSKY, V. P.; KAPELKO, V. I. Alterations in myocardial cytoskeletal and regulatory protein expression following a single Doxorubicin injection. Journal of Cardiovascular Pharmacology, New York, v. 41, n. 5, p. 788-794, 2003.

FALEIRO, M. B. R.; CROCE, G. B.; TOLEDO, D. C.; RODRIGUES, M. M. P.; BATISTA, A. C.; DAMASCENO, A. D.; BRITO, L. A. B.; AMORIM, R. L.; MOURA, V. M. B. D. Matrix metalloproteinases 2 and 9 expression in canine normal prostate and with proliferative disorders. Ciência Rural, Santa Maria, v. 43, n. 6, p. 1037-1043, 2013.

FERREIRA, A. L.; RUSSELL, R. M.; ROCHA, N.; PLACIDO LADEIRA, M. S.; FAVERO SALVADORI, D. M.; OLIVEIRANASCIMENTO, M. C.; MATSUI, M.; CARVALHO, F. A.; TANG, G.; MATSUBARA, L. S.; MATSUBARA, B. B. Effect of lycopene on doxorubicininduced cardiotoxicity: an echocardiographic, histological and morphometrical assessment. Basic \& Clinical Pharmacology \& Toxicology, Copenhagen, v. 101, n. 1, p. 16-24, 2007.

GRANADOS-PRINCIPAL, S.; QUILES, J. L.; RAMIREZ-TORTOSA, C. L. New advances in molecular mechanisms and the prevention of adriamycin toxicity by antioxidant nutrients. Food and Chemical Toxicology, Oxford, v. 48, n. 6, p. 1425-1438, 2010. 
IKEDA, K.; KAJIWARA, K.; TANABE, E. Involvement of hydrogen peroxide and hydroxyl radical in chemically induced apoptosis of HL-60 cells. Biochemical Pharmacology, New York, v. 57, n. 12, p. 1361-1365, 1999.

IQBAL, M.; DUBEY, K.; ANWER, T.; ASHISH, A.; PILLAI, K. K. Protective effects of telmisartan against acute doxorubicin-induced cardiotoxicity in rats. Pharmacological Reports, Kraków, v. 60, n. 3, p. 382390, 2008. Available at: <http://www.if-pan.krakow.pl/ pjp/pdf/2008/3_382.pdf>. Accessed at: 23 jun. 2013.

IVANOVÁ, M.; DOVINOVÁ, I.; OKRUHLICOVÁ, L.; TRIBULOVÁ, N.; ŠIMONČÍKOVÁ, P.; BARTEKOVÁ, M.; VLKOVIČOVÁ, J.; BARANČÍK, M. Chronic cardiotoxicity of doxorubicin involves activation of myocardial and circulating matrix metalloproteinases in rats. Acta Pharmacologica Sinica, Beijing, v. 33, n. 4, p. 459-469, 2012.

KARIMI, G.; RAMEZANI, M.; ABDI, A. Protective effects of lycopene and tomato extract against doxorbicininduced cardiotoxicity. Phytotherapy Research, London, v. 19, n. 10, p. 912-914, 2005.

KHAN, M.; SHOBHA, J. C.; MOHAN, I. K.; NAIDU, M. U.; SUNDARAM, C.; SINGH, S.; KUPPUSAMY, P.; KUTALA, V. K. Protective effect of Spirulina against doxorubicin-induced cardiotoxicity. Phytotherapy Research, London, v. 19, n. 12, p. 1030-1037, 2005.

KHASIGOV, P. Z.; PODOBED, O. V.; GRACHEVA, T. S.; SALBIEV, K. D.; GRACHEV, S. V.; BEREZOV, T. T. Role of matrix metalloproteinases and their inhibitors in tumor invasion and metastasis. Biochemistry, Moscow, v. 68, n. 7, p. 711-717, 2003.

KIZAKI, K.; ITO, R.; OKADA, M.; YOSHIOKA, K.; UCHIDE, T.; TEMMA, K.; MUTOH, K.; UECHI, M.; HARA, Y. Enhanced gene expression of myocardial matrix metalloproteinases 2 and 9 after acute treatment with doxorubicin in mice. Pharmacological Research, London, v. 53, n. 4, p. 341-346, 2006.

LI, Y. Y.; MCTIERNAN, C. F.; FELDMAN, A. M. Interplay of matrix metalloproteinases, tissue inhibitors of metalloproteinases and their regulators in cardiac matrix remodeling. Cardiovascular Research, London, v. 46, n. 2, p. 214-224, 2000.

MIGUEL, M. P.; MENEZES, L. B.; ARAÚJO, E. G. Fisiopatologia do estresse oxidativo após isquemia e reperfusão cerebral e potencial neuroproteção do pequi (Caryocar brasiliense). Enciclopédia Biosfera, Jandaia, v. 8, n. 15, p. 1960-1976, 2012.
MOURA, L. R.; ORPINELLI, S. R. T.; SOUSA, J. H.; FALEIRO, M. B. R.; CONCEIÇÃO, E. C.; SUGITA, D. M.; BELETTI, M. E.; MOURA, V. M. B. D. Ação do extrato etanólico da casca do pequi (Caryocar brasiliense) na cardiotoxicidade crônica induzida por doxorrubicina em ratos. Pesquisa Veterinária Brasileira, Rio de Janeiro, v. 37, n. 7, p. 713-724, 2017.

PONTES, J. C. D. V.; GOMES JÚNIOR, J. F.; SILVA, G. V. R.; BENFATTI, R. A.; DIAS, A. E. M. A. S. J.; DUARTE, J. J.; GARDENAL, N.; MAÇANORI ODASHIRO, M.; SANTOS, C. H. M. Estudo anatomopatológico da miocardiopatia induzida pela doxorrubicina em ratos. Acta Cirurgica Brasileira, São Paulo, v. 25, n. 2, p. 137-143, 2010.

POTÁČOVÁ, A.; ADAMCOVÁ, M.; STERBA, M. A.; POPELOVÁ, O.; SIMU゚NEK, T.; MAZUROVÁ, Y.; GUNCOVÁ, I.; GERSL, V. A pilot study of matrix metalloproteinases on the model of daunorubicininduced cardiomyopathy in rabbits. Acta Medica, Hradec Kralove, v. 50, n. 2, p. 109-111, 2007.

SILVA, S. N. S. Metaloproteinases da matriz 2 e $9 \mathrm{em}$ coelhos com cardiomiopatia induzida pela doxorrubicina. 2014. Dissertação (Mestrado em Medicina Veterinária) Universidade Estadual Paulista, Jaboticabal.

STEINHERZ, L. J.; STEINHERZ, P. G.; TAN, C. T. C.; HELLER, G.; MURPHY, M. L. Cardiac toxicity 4 to 20 years after completing anthracycline therapy. Journal of the American Medical Association, Chicago, v. 266, n. 12, p. 1672-1677, 1991.

WALKER, J. R.; SHARMA, A.; LYTWYN, M.; BOHONIS, S.; THLIVERIS, J.; SINGAL, P. K.; JASSAL, D. S. The cardioprotective role of probucol against anthracycline and trastuzumab-mediated cardiotoxicity. Journal of the American Society of Echocardiography, Saint Louis, v. 24, n. 6, p. 699-705, 2011.

XIN, Y. F.; WAN, L. L.; PENG, J. L.; GUO, C. Alleviation of the acute doxorubicin-induced cardiotoxicity by Lycium barbarum polysaccharides through the suppression of oxidative stress. Food and Chemical Toxicology, Oxford, v. 49, n. 1, p. 259-264, 2011.

YU, P. C.; CALDERARO, D.; IKEOKA, D. T.; DEMARCHI, L. M. M. F.; CARAMELLI, B. Toxicidade miocárdica por doxorrubicina. Revista da Associação Médica Brasileira, São Paulo, v. 51, n. 3, p. 121-132, 2005. 